\title{
ASSESSMENT OF TECHNOGENIC RISKS IN RECOVERING COMPANY FOR WORN TYRES
}

\author{
Mihails Urbans, Inese Vilcane, Jelena Malahova \\ Riga Technical University, Latvia \\ mihails.urbans@riga.lv, inese.vilcane@rtu.lv, jelena.rtu@inbox.lv
}

\begin{abstract}
Global statistics shows that the number of cars worldwide is increasing every year, leading to an increase in the number of worn-out tyres, for which efficient and safe recovering is a problem. There exists a variety of technologies that help get raw materials from recovering worn-out tyres or use them as a source of energy. Recovery of worn-out tires is an urgent necessity worldwide. In accordance with the European Union Directive 1999/31/EC, burial of refuse tyres is prohibited and as an alternative they would have to be recycled. On the one hand, the increasing pace of industrialization is causing ecological problems; while on the other, worn-out tyres are valuable raw materials. A case analysis study - assessment of environmental impact of the performance process of a tyre recovering plant in Lithuania (hereinafter - the object) - was performed. For the object assessment, qualitative and quantitative data acquired by experts during inspection were used. In the study, the authors assess and analyze the impact of potential technogenic risks of the object processes on the environment and population. The aim of the research is to perform risk identification, assess potential consequences and determine their amount. On the basis of the data acquired at the object the authors of the study find out what shortcomings exist in the process of recovering of worn-out tyres, what is the actual situation in the safety system at the object and what are the environmental consequences of emergency situations. The main hazards are caused by the risk of tyre fire, because such fire is very difficult to extinguish and harmful smoke is released as a result of combustion thus contaminating the atmosphere with substances harmful to the environment and human organism. Tyres are combustible material, additional hazards include ecotoxic effects. It was found that at 100-metre distance from the epicenter during fire of the tyre housing concentration was $1.07 \cdot 10^{-7} \%$. Thus, dangerous consequences for people within 100 meters at the ground level are not associated with dangerous concentration of carbon monoxide.
\end{abstract}

Keywords: tyre fire, hazard, cancer risks, environmental pollution, worn-out tyre recovering.

\section{Introduction}

Over the past decades, there has been a significant increase in the number of tyres produced worldwide $[1 ; 2]$ and therefore they should be destroyed as a waste at the end of their lives. The total output of tyres in the European Union, which are produced in about 90 factories, is approximately 355 million per year, which corresponds to about $24 \%$ of the total world production [3;4]. In the coming years, the number of tyres produced in the world is expected to reach 1.7 billion units. This means that more than 290 million tyres are thrown out each year in the US, while the EU, as well as Norway and Switzerland, generate about 3.2 million tons of used tyres (partly worn + worn-out tires), of which 2.5 million tons are recycled or recovered [3;5]. Recovery of waste tyres is very problematic and dangerous for the environment and human health [6]. Consequently, the increasing number of used tyres poses a serious threat $[3 ; 7 ; 8]$.

In case of a typical tyre composition [9], the tyre rubber component is a mixture of multiple rubbers reinforced with a carbon filler. The tyre design includes a composite of rubber layers. It uses various straps and cords (metal) of synthetic and natural rubber, including styrene-butadiene rubber, natural rubber (polyisoprene), nitrile rubber, chloroprene rubber, polybutadiene rubber, textile, steel and additives. This means that the tyres are combustible. In this context, it has been established that it is an uncontrolled tyre fire and produces a number of air pollutants, including carbon monoxide (CO), sulphur oxides (SO2), nitrogen oxides (NOx) and volatile organic compounds (VOCs) [10]. The emission of these pollutants from an open-air tyre fire can mean serious acute and chronic health hazards for the population in the vicinity of the fire [3]. Risk of combustion is a key issue associated with recovering of tyres. This risk is first related to large stockpiles of used tyres. The larger the tire stockpiles, the larger the fire and fire load that puts other objects at risk of fire. Consequently, this increasing number of used tyres means a serious threat to the natural environment [8].

Thus, it is of utmost importance that the companies that recycle worn tyres are prepared to increase the recovering rates without compromising the environment, so that the ongoing processes are safe for the environment. This study provides an opportunity to look at the actual state of the tyre recovering company and its compliance with the world's best safety standards. 
The subject of the study is topical all over the world, especially in the context of environmental and technological safety. It was concluded that the shortcomings of the technogenic environment safety system identified could be extended also to other local and international tire recovering companies that may have a similar situation. In a company in case of fire the atmosphere, in which toxic fumes are released, is mainly exposed to the hazard. Delayed effects are also associated with bioresources and water resources, for which the impact of hazard factors was not investigated within the framework of the present study.

The aim is to identify the drawbacks and the technogenic environment risks existing in recovering of worn tyres; to assess the situation at the facility and with security systems; to assess the possible environmental impact in case of emergency situation. Such study is relevant not only in the Baltic States, but also throughout Europe and all over the world.

\section{Materials and methods}

A case study was carried out - environmental impact assessment of the operating process at the tyre recovering plant in Lithuania (hereinafter referred to as the object). The study used mixed methods - qualitative and quantitative. The experts' group conducted a site survey to detect compliance or non-compliance with various regulatory requirements and different guidelines for labour protection, fire safety and civil protection; conducted verbal interviews with the company representatives about the situation at the object; conducted a company document survey to retrieve data. The resulting data were processed and new data were obtained for the calculation.

The following calculations were carried out: tyre storage area: $\mathrm{m}^{2}, \%$; total number of tyres in $\mathrm{kg}$; tyre mass in $\mathrm{kg}$ per $1 \mathrm{~m}^{2}$; total heat load of tires $\mathrm{MJ} \cdot \mathrm{m}^{-2}$; calculation of burn time $t_{m}$ in $0.9 \mathrm{~kg} \cdot \mathrm{m}^{-2} \cdot \mathrm{min}$; calculation of heat radiation of fire $q, \mathrm{~kW}$; release of carbon dioxide and carbon monoxide into atmosphere in $\mathrm{g} \cdot \mathrm{min}^{-1}$; carbon dioxide concentration during tyre burning within entire warehouse area $C(x, 0,0), \mathrm{Cog} \cdot \mathrm{m}^{-3}$.

The obtained data provided the experts' group with an opportunity to evaluate the impact of possible technogenic risks on the environment and population.

\section{Assessment of the object risks}

The factory is based in Lithuania and has been operating since 2011, being the only tyrerecovering company in the Baltics, with daughter enterprises registered in Latvia, Estonia and the Russian Federation. In 2011, the company has recycled more than 30,000 tons of used tyres, and in 2012 the recovering company has produced more than 12,000 tons of rubber granules and $40,000 \mathrm{~m}^{2}$ of rubber coating. More than 64 employees are working at the studied object,the maximum number of people including visitors in the territory being 70 [11].

The object is located in the industrial building area of the city. Next to the object,there are companies dealing with oil product transshipment andstorage, which may hypothetically cause an industrial accident at the object or cause more serious consequences. Accidents near the object may occur on the nearby railway or in other adjacent companies, as well as in the area near the company, where other dangerous substances are transported (such as petrol, diesel or other oil products). The main activity of the factory is related to tyrerecovering, production and marketing of rubber products resulting from the processing. Tyre housings at the object are shown in Figure 1, using Google earth cartographic material.

Maximum amount of tyres stored at the object prior to recovering is $300 \mathrm{t}$ of tyres of various types (light cars, lorries etc.). Distribution of the housing territory area and tyre mass by housings is summarized in Table 1. The authors conclude that the total area of the open-air warehouse occupied in the territory by the stored tyres is $1,301.48 \mathrm{~m}^{2}$.

Tyre housings are not mutually separated by special enclosures, so in the event of a fire in one of the housings the effect of heat radiation can lead to ignition of also other nearby buildings with tyres or the finished products - crushed rubber residues with a lower ignition temperature than the tyres. There may be a domino effect, if no measures are taken to relocate other materials being in the housings. All substances and materials stored in the object territory are potential sources of energy which, in the event of fire, generate heat. The heat of rubber combustion is $33.5 \mathrm{MJ} \cdot \mathrm{kg}^{-1}$ [12]. In case 
of rubber burning, a large amount of heat is released, which is similar to that of coal. One of the most important characteristics that determine the fire hazard of materials is the combustion rate. It determines the intensity of the heat radiation, and therefore the rate of fire propagation and the intensity of the heat radiation in the area adjacent to the fire pit. The intensity of heat radiation, in turn, determines the safe distances $(\mathrm{m})$, at which the rescue service personnel can be when extinguishing the fire. The self-ignition temperature of the rubber depends on its dispersion and composition. In compact condition, the rubber ignition temperature is $275^{\circ} \mathrm{C}$, but for crushed rubber residue (granule) it is $112^{\circ} \mathrm{C}$. Under the influence of direct flame on the rubber, the ignition takes place after $\sim 1.5$ minutes and after $2.5 \mathrm{~min}$ the tyres burn throughout the entire area [13].

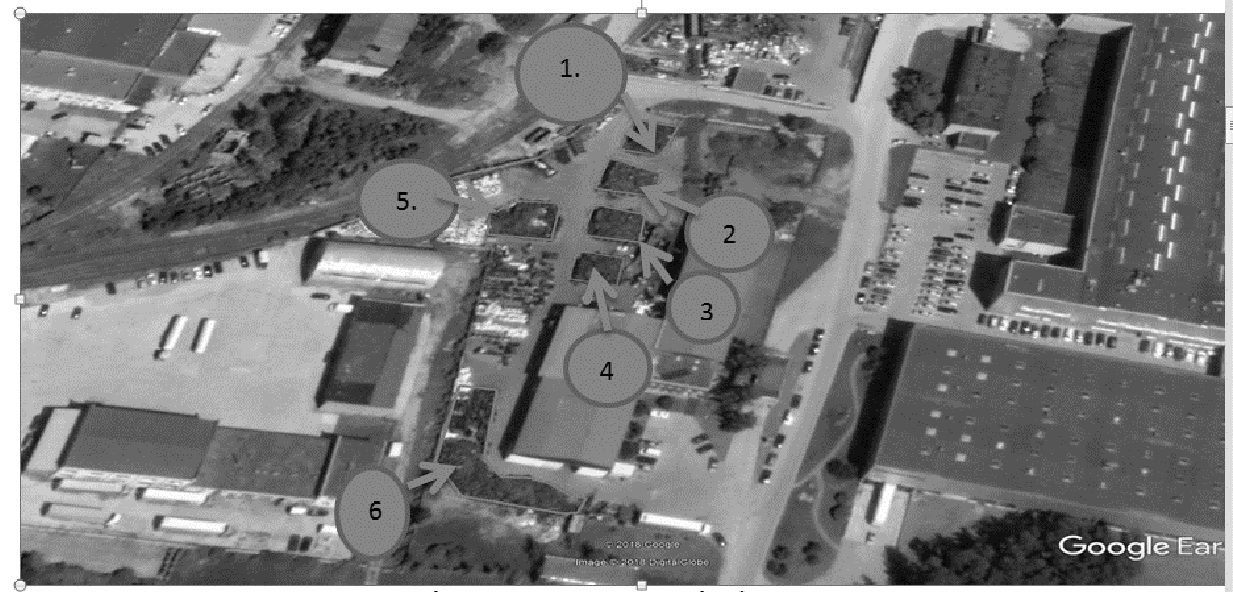

Fig. 1. Tyre housings 1 - 6 in object territory

Table 1

Tyre mass distribution by housings

\begin{tabular}{|c|c|c|c|c|}
\hline No. & Tyre warehouse area, $\mathbf{~ m}^{\mathbf{2}}$ & $\mathbf{\%}$ & Total amount, $\mathbf{~ g}$ & Mass in kg per $\mathbf{~ m}^{\mathbf{2}}$ \\
\hline 1. & 146.30 & 11.24 & 33,720 & 230.48 \\
\hline 2. & 162.75 & 12.50 & 37,500 & 230.41 \\
\hline 3. & 155.00 & 11.91 & 35,730 & 230.51 \\
\hline 4. & 123.67 & 9.50 & 28,500 & 230.45 \\
\hline 5. & 211.80 & 16.27 & 48,810 & 230.45 \\
\hline 6. & 501.89 & 38.56 & 115,680 & 230.48 \\
\hline Total & $\mathbf{1 , 3 0 1 . 4 8}$ & $\mathbf{1 0 0}$ & $\mathbf{3 0 0 , 0 0 0}$ & $\mathbf{2 3 0 . 5 0}$ \\
\hline
\end{tabular}

The total heat load of the tyres upon burning down of all tyres in each housing is determined using the formula (1):

$$
g=\frac{\sum m_{i} \cdot Q_{H i}}{S}
$$

where $m$-material mass, $\mathrm{kg}$;

$g$ - heat amount $\mathrm{MJ} \cdot \mathrm{m}^{-2}$;

$Q_{H i}$ - lowest calorific valueupon burning down of rubber $14100^{6} \mathrm{~kJ} \cdot \mathrm{kg}$;

$S$ - housing area, $\mathrm{m}^{2}$.

In open-area fires a part of heat released in the combustion areas with radiation and convection is 40-50\%; the remainder heats up the other combustion products, while other hard combustion materials of organic origin have on the average the combustion temperature of $1100-1250{ }^{\circ} \mathrm{C}$. The total heat potential calculated using formula (1) is summarized in Table 2, as well as the total burning time of tyres, which depends on the mass of the product in each housing.

Formula (2) was used to calculate the burnout time, see Table 2 for the obtained results.

$$
t=\frac{m}{t_{m} \cdot S},
$$


where $m$-material mass, $\mathrm{kg}$;

$t_{m}$ - rubber burnout velocity $0.9 \mathrm{~kg} \cdot \mathrm{m}^{-2} \cdot \mathrm{min}$;

$S$ - housing area, $\mathrm{m}^{2}$.

Fire heat radiation released at the place of burning is $q=22612 \mathrm{~kW}$ within the specified time period $t=1 \mathrm{~min}$ and is calculated using formula (3):

$$
q=t_{m} \cdot Q_{H} \cdot \beta
$$

where $\beta$-combustion efficiency, 0.75 ;

$Q_{H}$ - calorific value upon burning down of rubber $33500 \mathrm{~kJ} \cdot \mathrm{kg}^{-1}$.

Table 2

Total heat potential and burnout time

\begin{tabular}{|c|c|c|c|c|c|c|}
\hline No. & $\begin{array}{c}\text { Tyre } \\
\text { warehouse } \\
\text { area, } \mathrm{m}^{2} \\
\end{array}$ & $\begin{array}{c}\text { Total } \\
\text { quantity, } \\
\mathrm{kg}\end{array}$ & $\begin{array}{l}\text { Lowest calorific value } \\
\text { upon burning down of } \\
\text { rubber, } \mathrm{kJ} \cdot \mathrm{kg}^{-1}\end{array}$ & $\begin{array}{l}\text { Heat amount } g \text {, } \\
\text { MJ } \cdot \mathrm{m}^{-2}\end{array}$ & $\begin{array}{l}\text { Burnout time } \\
t \text {, hours }\end{array}$ & $\begin{array}{l}\text { Burnout } \\
\text { products, } \\
\mathrm{g} \cdot \sec ^{-1}\end{array}$ \\
\hline 1. & 146.3 & 33,720 & 14,100 & $3,249,891.0$ & 4.26 & $2,194.50$ \\
\hline 2. & 162.75 & 37,500 & 14,100 & $947,323.1$ & 4.26 & $2,441.25$ \\
\hline 3. & 155 & 35,730 & 14,100 & $1,053,518.0$ & 4.26 & $2,325.00$ \\
\hline 4. & 123.67 & 28,500 & 14,100 & $1,003,792.0$ & 4.26 & $1,855.05$ \\
\hline 5. & 211.80 & 48,810 & 14100 & $800,673.5$ & 4.26 & $3,177.00$ \\
\hline 6. & 501.89 & 115,680 & 14,100 & $1,371,259.0$ & 4.26 & $7,528.35$ \\
\hline
\end{tabular}

The calculations show that there is a large amount of tyres stored at the object, which in case of burning will release a high heat radiation and harmful combustion products. The team of experts at the object during the inspection survey have found still more various incompliances with fire safety and labour protection requirements, which could endanger the health and safety of people there.

- The maximum size for the housing is not exceeded, but the distances at the storage from the housing edge to the fence and buildings are not observed, because the tyres are stacked immediately at the fence instead of $15 \mathrm{~m}$ as specified; the building where tyres are being recycled is in the immediate vicinity and not $60 \mathrm{~m}$ away. Firebreaks of $18 \mathrm{~m}$ between housings are not observed.

- Free flushing of hazardous substances from tyres is allowed, since they are kept in piles, while the confining edges that may serve as a containment during the fire are not created.

- As well as the fence of the object is lower than 3 metres, anti-tampering systems to prevent unauthorized persons from entering the object are not installed and there is no physical security at the object.

- Access roads for emergency services are narrower than it is established in the recommendations, there is no plan of the territory with the road traffic diagram, and there are no specified safety signs for traffic regulation.

- Road pavement in the territory is in poor condition, resulting in significant spillage of finished products across the area and damage to the container.

- Labour protection (LP) incompliances: insufficient lighting; risk of traumatism due to chaotic layout of mobile equipment and products as well as through the absence of LP safety signs and labelling; personal protective equipment is not always used.

- Leakage of equipment causes serious losses of rubber granules indoors, which later settle in the form of dust on production equipment and communications;

- The condition of indoor premises (workshops) evidences a large amount of dust in the work area, during the recovering and production process, which in turn points to inefficient operation of the ventilation system. Besides, dust can cause occupational respiratory tract diseases in workers.

In order to reduce the object's hazard associated with open-area storage of tyres, the authors propose a US example of good practice regarding the temporary storage of tyres [14]. As well as recommendations in the New Zealand's guidelines on the prevention and management of scrap tyres that it is possible to reduce the risk of fire and the possible domino effect between tire housings by setting minimum distances between the tyre housings [15]. In addition, the authors' group 
recommends reviewing the arrangement of the labour protection system at the object and the prevention of identified work environment risks in accordance with the requirements of regulatory enactments, as well as the subsequent risk assessment of the work environment.

\section{Hazard of rubber burning}

The automobile tyre consists of rubber made of natural or synthetic rubber, carbon black, silicica, oil and resins, sulfur and woven fabrics - chord that can be made in the form of metals, polymers or fiberglass. Rubber burning emits black smoke, mainly containing two toxic gases: hydrogen sulphide and sulphur dioxide, as well as $270 \mathrm{~kg}$ of soot and $450 \mathrm{~kg}$ of toxic gas, when burning down one ton of tyre high combustion temperature bars from efficient performance of fire extinguishing works. [16] Burning of 1,000,000 tyres generates about 2,000,00 1 of petroleum products as well as other chemicals that pollute groundwater and soil during the process of fire extinguishing with water, so it is important to prevent contaminated water from entering the soil as well as into the sewage system [17]. In addition, the scientific literature indicates that the combustion process has a lower, when spraying equipment is used to extinguish fires, but this leads to higher emissions of carbon monoxide and unburned organic substances. Emissions of other substances are lower, especially dust emissions, since they are flushed out of smoke [18].

The authors use Pasquill-Gifford nomograms that are based on the Bruges approach to determine dangerous concentration of carbon dioxide during the burning of tyres in the full area of the warehouse No.6. Meteorological conditions may remain unchanged for 2-3 hours, and then at 2-3 $\mathrm{m} \cdot \mathrm{s}^{-1}$ wind speed the hazardous substances can reach $20-30 \mathrm{~km}$ distance from the site of event. The following parameters were accepted for the calculations: atmospheric stability class $\mathrm{F}$ and wind speed $2 \mathrm{~m} \cdot \mathrm{s}^{-1}$. The following formula was used (4):

$$
C(x, 0,0) \frac{G_{0}}{2 \cdot \pi \cdot U \cdot \partial_{y}(x) \partial_{z}(x)}
$$

where $C(x, 0,0)$ - hazardous substance concentration at the reviewed point;

$G_{0}$ - hazardous substance emission intensity, $\mathrm{g} \cdot \mathrm{m}^{-2} \cdot \mathrm{s}$;

$U$ - wind speed, $\mathrm{m} \cdot \mathrm{s}^{-1}$

$\partial_{y}, \partial_{y}-$ slope location in the flow.

Formula (4) was used to obtain the results (shown in Table 3) on $\mathrm{CO} \mathrm{g} \cdot \mathrm{m}^{-3}$ and $\mathrm{CO}_{2} \mathrm{~g} \cdot \mathrm{m}^{-3}$ concentration depending on the distance on the $\mathrm{X}$-axis on the ground level from the accident place in wind direction.

Table 3

$\mathrm{CO} \mathrm{g} \cdot \mathrm{m}^{-3}$ and $\mathrm{CO}_{2} \mathrm{~g} \cdot \mathrm{m}^{-3}$ concentrations depending on distance

\begin{tabular}{|c|c|c|c|c|c|c|c|c|}
\hline Distance, $\mathbf{m}$ & 100 & 200 & 500 & 1000 & 2000 & 3000 & 5000 & 10000 \\
\hline $\begin{array}{c}\text { Concentration } \\
\mathbf{C O}, \mathbf{g} \cdot \mathbf{m}^{-3}\end{array}$ & 0.52 & 0.141 & 0.0276 & 0.00892 & 0.003198 & 0.001843 & 0.00963 & 0.000426 \\
\hline $\begin{array}{c}\text { Concentration } \\
\mathbf{C O}_{\mathbf{2}}, \mathbf{g} \cdot \mathbf{g}^{-3}\end{array}$ & 21.60 & 5.8512 & 1.144972 & 0.36 & 0.132505 & 0.076344 & 0.039898 & 0.017667 \\
\hline
\end{tabular}

When calculating for the atmospheric stability class $\mathrm{F}$ at $2 \mathrm{~m} \cdot \mathrm{s}^{-1}$ wind speed, it was found that at 100 meters from the epicenter on the X-axis the CO concentration is $0.52 \mathrm{~g} \cdot \mathrm{m}^{-3}$, which corresponds to $520 \mathrm{mg} \cdot \mathrm{m}^{-3}$ or $0.052 \%$ and means that the following health problems are expected for the recipients: light headache, decreased mental disabilities and physical capacities, short breathing at moderate physical load, deficiencies of visualization associated with eye resolution. It can be fatal to people with severe heart problems. At 200 meters, the $\mathrm{CO}$ concentration is $0.141 \mathrm{~g} \cdot \mathrm{m}^{-3}$, which corresponds to $141 \mathrm{mg} \cdot \mathrm{m}^{-3}$ or $0.0121 \%$; at such $\mathrm{CO}$ concentration a reduction can be expected in psychomotor reactions, sometimes a compensatory increase in the blood flow to vital organs. According to the data in Table 3, the CO concentration at farther distances from the accident site only decreases, which does not cause consequences for the population. The CO limiting concentration value is $0.68 \mathrm{~g} \cdot \mathrm{m}^{-3}$, and it is found that this limiting value is not reached, while fatal CO concentration of $5.72 \mathrm{~g} \cdot \mathrm{m}^{-3}$ for 10 -minute exposure is very far away. Under the same atmospheric conditions, the $\mathrm{CO}_{2}$ concentration at 100- 
metre distance from the epicenter on the $\mathrm{X}$-axis is $21.60 \mathrm{~g} \cdot \mathrm{m}^{-3}$, which is $21600 \mathrm{mg} \cdot \mathrm{m}^{-3}$, or $1.18 \%$, which does not cause visible effects in human body.

\section{Conclusions}

1. The main danger withtyres is their ability to catch fire, it is very difficult to extinguish in case of fire and harmful smokes emit as a result of burning, thus polluting the atmosphere with substances harmful to the environment and the human body. The ignition temperature is $112^{\circ} \mathrm{C}$ for rubber pellets and $270{ }^{\circ} \mathrm{C}$ for tyres while the burning temperature is very high and reaches $1200{ }^{\circ} \mathrm{C}$, black smoke is released during the combustion process. Tyres are a fire-hazardous material, although not inflammable, with additional hazard of ecotoxic effect.

2. Performing calculations for the atmospheric stability class $F$ at wind speed of $2 \mathrm{~m} \cdot \mathrm{s}^{-1}$, it was found that at 100-metre distance from the epicenter during fire of the tyre housing No. 6, the CO concentration was $1.07 \cdot 10^{-7} \%$. Thus, dangerous consequences for people within 100 meters at the ground level are not associated with dangerous concentration of carbon monoxide. Under the same atmospheric conditions, the $\mathrm{CO} 2$ concentration is $1.24 \%$, which according to the literature data does not cause any visible consequences for people.

3. The total assessment of the production premises and outdoor area is negative, significant spillage of finished products has been found, which is formed as a result of transportation by roads with pavement in emergency condition. Spillage also occurs as a result of damage to the container wherein the crushed rubber waste is stored.

4. Distances between product warehouses are not sufficient to avoid hazard for another housing or for own buildings of the object. Layout of raw materials in the territory is very poorly organized, finished products are stored together with raw materials.

5. Upon burning at the enterprise, the mainly exposed to hazard area is the atmosphere where toxic fumes are released, the delayed effect is also associated with bio-resources and water resources, for which the impact of hazardous factors has not been reviewed.

\section{References}

[1] European Tyre \& Rubber Manufacturers' Association, End-of-life tyres management report 2011. [online][27.12.2018]. Available at: http://www.etrma.org/uploads/Modules/Documentsmanager/brochure-elt-2011-final.pdf

[2] Martíneza J.D., Puy N., Murillo R., García T., Navarro M.V., Mastral A.M. Wastetyrepyrolysis A review. Renewable and Sustainable Energy, vol. 23, 2013, pp. 179-213.

[3] Nadal M., Rovira J., Díaz-Ferrero J., Schuhmacher M., Domingo L. J. Human exposure to environmental pollutants after a tire landfill firein Spain: Health risks. Environment International, vol. 97, 2016, pp. 37-44.

[4] ETRMA. Statistics. European Tyre Rubber Manufactures Association. [online][20.12.2018]. Available at: http://www.etrma.org/statistics-2.

[5] ETRMA. End of Life Tyres. European Tyre Rubber Manufactures Association. [online][20.12.2018]. Available at: http://www.etrma.org/tyres/ELTs.

[6] Czajczyńska D., Krzyżyńska R., Jouhara H., Spencer N. Use of pyrolytic gas from waste tire as a fuel: A review. Energy, vol. 134, 2017, pp. 1121-1131.

[7] Jang J.W., Yoo T.S., Oh J.H., Iwasaki I. Discarded tire recovering practices in the United States, Japan and Korea. Resources, Conservation and Recovering. 22, 1998, pp. 1-14.

[8] Hennebert P., Lambert S., Fouillen F., Charrasse B. Assessing the environmental impact of shredded tires as embankment fill material. Canadian Geotechnical Journal. 51, 2014, pp. 469-478.

[9] Evans A., Evans R. The Composition of a Tyre: Typical Components. Waste\& Resources Action Programme, Banbury Oxford. [online] [20.12.2018]. Available at: http://www.wrap.org.uk/ sites/files/wrap/2 \%20- \%20Composition \%20of \%20a \%20Tyre \%20- \%20May \%202006.pdf

[10] Reisman J. Air Emissions From Scrap Tire Combustion. U.S. Environmental Protection Agency, Washington, D.C. EPA/600/R-97/115 (NTIS PB98-111701). [online] [20.12.2018]. Available at: https://cfpub.epa.gov/si/si_public_record_Report.cfm?Lab = NRMRL\&dirEntryID = 115147 
[11] Metaloidas. Products. [online] [12.09.2018]. Available at: http://www.metaloidas.lt/en/rubberproducts/

[12] Thermal info. Удельная теплота сгорания топлива и горючих материалов (Specific heat of combustion of fuel and combustible materials). (In Russian). [online] [12.09.2018]. Available at: http://thermalinfo.ru/eto-interesno/udelnaya-teplota-sgoraniya-topliva-i-goryuchihmaterialov\#teplota-sgoraniya-goruchikh-materialov.

[13] Киреев А. А., Каракулин А. Б., Жерноклёв К. В. Экспериментальное определение массовой скорости горения (Experimental determination of the mass burn rate). Сборник научных трудов. Collection of scientific papers, 35, 2014 (In Russian).

[14] Panamerican Health Organization (Washington). The Prevention \& Management of Scrap Tire Fires. [online] [12.09.2018]. Available at: http://www.bvsde.paho.org/bvsacd/cd48/ fire_prevention.pdf

[15] Ministry for the Environment (New Zealand). End-of-Life Tyre Management: Storage Options, Final Report for the Ministry for the Environment, 2004. [online] [12.09.2018]. Available at: http://www.mfe.govt.nz/publications/waste/end-of-life-tyre-managementjul04/end-of-life-tyremanagement.pdf.

[16]Протасов Н.В. Проблемы жизненного пути изношенной шины (Worn tire life problems). Applied forest: Деловой Лес. vol 1 (133), 2012. pp. 49-51. (In Russian).

[17]Коршунов И.В. Организация газодымозащитной службы (Organization of gas and smoke protection services)// Продукты горения и влияние их на организм человека (Products of combustion and their effect on the human body). StudRef, 2017. (In Russian).

[18] Technical guidelines. Revised technical guidelines for the environmentally sound management of used and waste pneumatic ctyres. Hazardous Wastesand Their Disposal Tenthmeeting, 2011. [online] [12.09.2018]. Available at: UNEP/CHW.10/6/Add.1/Rev.1. Distr.: General 11 November 2011 English. 